\title{
Diagnosed Changes of Bone Mineral Density and Level of Calciotropic Hormones in Juvenile Hyperthyroidism
}

Shakhlo Muratova ( $\sim$ shakhlo.muratova@gmail.com)

Republican Specialized Scientific-Practical Medical Center of Endocrinology named after academician Ya.Kh.Turakulov

\section{Research}

Keywords: children, adolescents, thyrotoxicosis, bone mineral density, vitamin D, parathyroid hormone, osteoporosis

Posted Date: February 22nd, 2021

DOl: https://doi.org/10.21203/rs.3.rs-160165/v1

License: (c) (i) This work is licensed under a Creative Commons Attribution 4.0 International License.

Read Full License 


\section{Abstract}

In childhood and adolescence, a genetically determined bone mass accumulates, which ensures the strength of the skeleton throughout life. But with thyrotoxicosis, a separation of the processes of bone resorption and synthesis and the formation of sites of osteoporosis and osteosclerosis occur, leading to the loss of $10 \%$ of bone mass in 1 cycle of remodeling. Because of the lack of information about this phenomenon, our work aimed to study the state of bone mineral density and levels of calciotropic hormones in children and adolescents with thyrotoxicosis. The study was conducted by 19 children and adolescents with thyrotoxicosis. The control group consisted of 23 healthy children and adolescents. All studies were conducted in the RSSPMCE. Thyroid status, PTH and vitamin D were determined using a closed-type immunochemistry analyser Cobas e 411 Hitachi company HoffmanLeRoche (Switzerland) and its reagents. Bone mineral density was evaluated by dual-energy absorptiometry on a Stratos X-ray densitometer from DMS, France. The results of the study showed that the average value of the level of vitamin $D$ in the group with thyrotoxicosis was $12.3 \pm 1.1 \mathrm{ng} / \mathrm{ml}$, against $20.4 \pm 6.2 \mathrm{ng} / \mathrm{ml}$ of the control group, while its deficiency was diagnosed in $84.2 \%$, and its insufficiency - in $15.8 \%$ of pediatric patients. In the group with thyrotoxicosis, the average level of PTH was lower and amounted to $45.1 \pm 23.9 \mathrm{ng} / \mathrm{ml}(\mathrm{p}$ $<0.05)$ compared with the control $(49.2 \pm 21.3 \mathrm{ng} / \mathrm{ml})$; hypoparathyroidism was found in 4.9 times more often than among healthy children, and $21.1 \%$ showed an increase in the level of PTH. In children and adolescents with thyrotoxicosis Z- index of the femoral neck, lumbar vertebrae and the general body were significantly lower than in the control group. $36.8 \%$ of children with thyrotoxicosis have osteoporosis. Conclusion: Thyrotoxicosis in children and adolescents causes a decrease in BMD and majorly increases the development of osteoporosis.

\section{Background.}

In recent decades, a decrease in bone mineralization in children has attracted close attention in connection with the proof of its role in the development of osteoporosis (OP) in adulthood and old age. Several publications explicitly state: "the origins of adult osteoporosis are in childhood" [1, 2]. During this period, the skeleton grows intensively and bone mass increases. Of particular importance is the period of puberty, since by its completion the bone mass in many parts of the skeleton reaches $86 \%$, and in certain areas up to $100 \%$ of the bone mass of an adult. Back in 1973, Dent C.E. noted that senile OP is a "pediatric" disease. After all, it is precisely in childhood and adolescence that a genetically determined bone mass is accumulated, which ensures the strength and resistance of the skeleton to the effects of various adverse factors throughout life [3]. Along with this, many endogenous and exogenous factors can cause children to deviate from the genetic development program, including bone tissue, both before and after birth [4]. At the same time, in children and adolescents, osteoporosis is often secondary, as a consequence of the most diverse diseases in aetiology [5].

An ongoing study of the state of bone mineral density (BMD) showed that there is a clear relationship between its decrease and thyrotoxicosis. The thyroid system has a special role in regulating the growth and development of the skeletal system, enhancing metabolic processes, intensifying growth processes, 
and the maturation of organs and systems [6]. The physiological effect of thyroid hormones is manifested by the linear growth of tubular bones, which is accelerated to puberty and the closure of growth zones. With thyrotoxicosis, there is a separation of the processes of bone resorption and synthesis, the formation of sites of osteoporosis and osteosclerosis; the time of all phases of bone remodeling decreases, and the frequency of occurrence of remodeling sites increases, i.e. the activity of osteoblasts and osteoclasts increases, and the remodeling cycle is reduced by $50 \%$.

These changes are disproportionate, which leads to a loss of $10 \%$ of bone mass per 1 cycle of remodeling [7], the decomposition of the protein (collagen) matrix of bone is accelerated, bone demineralisation and negative calcium balance are observed. In children and adolescents with thyrotoxicosis, the rate of skeleton bone maturation is accelerated; in infants, early development of the skeleton, including craniosynostosis, is observed, and the bone mineral density in different parts of the skeleton decreases $[8,9]$. On radiographs in children with thyrotoxicosis, changes resembling menopausal osteoporosis are detected. The growth of the child is accelerated at first, but the fusion of the epiphyses of the long bones occurs earlier than the due date, and the final growth may be less than normal [10].

In 1998, due to the growing incidence of OP, a WHO working group was created, as a result of which recommendations were developed for the prevention and treatment of this disease. One of the first recommendations said: "... it should be remembered that the prevention of osteoporosis begins with the proper bone formation during the growth period. It is necessary to identify and correct factors affecting bone formation in childhood" [11]. At the same time, questions about the prevalence of decreased BMD remain poorly understood, data on the content of parathyroid hormone in patients with thyrotoxicosis in children and adolescents are contradictory. There is very little information in the literature on the state of bone metabolism in children and adolescents with thyrotoxicosis. Moreover, early initiation of therapy, the duration of medical treatment, and the development of its complications can have a negative effect on the formation of the organism of children as a whole.

\section{Purpose of the study}

to research the state of bone mineral density, levels of vitamin $D$ and parathyroid hormone in children and adolescents with thyrotoxicosis.

\section{Material And Methods.}

The study included children and adolescents with thyrotoxicosis in the active phase at the age of 9-18 years, $n=33$. The control group consisted of children and adolescents, healthy for osteopathy, without endocrine pathology, $n=23$, of a similar age, who were not affected by risk factors for reducing BMD.

The diagnosis of thyroid gland pathology and other systems was based on anamnesis, clinical manifestations, biochemical and hormonal laboratory tests, thyroid ultrasound, fine-needle aspiration biopsy of the thyroid gland according to indications), which were carried out in the RSSPMCE named 
after academician Ya.Kh. Turakulov. TSH levels, free T4 and freeT3, parathyroid hormone (PTH) and vitamin D were determined using a closed-type immunochemistry analyzer Cobas e 411 Hitachi from Hoffman Le Roche (Switzerland) and its reagents.

The parathyroid hormone level in the range of $15.0-65.0 \mathrm{pg} / \mathrm{ml}$, presented in the test system, was adopted as reference values of PTH. Interpretation of vitamin D levels was performed according to the classification of the European Society of Clinical and Economic Aspects of Osteoporosis and Osteoarthritis with the support of the International Osteoporosis Fund (IOF), where severe vitamin D deficiency is diagnosed at a concentration of $<10 \mathrm{ng} / \mathrm{ml}$, deficiency $<20 \mathrm{ng} / \mathrm{ml}$, insufficient vitamin $D$ with values $\geq 20$ and $<30 \mathrm{ng} / \mathrm{ml}$, a sufficient content at a vitamin concentration of more than $30 \mathrm{ng} / \mathrm{ml}[12,13]$.

Osteodensitometry, which is the most preferred method for assessing bone mass and BMD in children and adolescents, is considered the "gold standard" for diagnosing of OP. In the studied children and adolescents, BMD was evaluated by dual-energy absorptiometry (DEXA) on a Stratos X-ray densitometer from DMS (France) using the Asian M normative curves Pediatrics Rachis, left and right Femur and Total body from DMS normality curves 2003/2004 in RSSPMC of Traumatology and Orthopedics. The measurement results were expressed in absolute values of BMD (bone mineral density $-\mathrm{g} / \mathrm{cm} 2$ ) and the form of a Z-score (Z-criterion), according to the generally accepted criteria for the diagnosis of osteoporosis WHO. The measurements were carried out in two standard areas of the skeleton: the lumbar spine (L1-L4) and the proximal femur. When interpreting data for the diagnosis of OP, the Total body indicator in the values of standard deviations is estimated. The recommendations of the International Society for Clinical Densitometry indicate that BMD and BMC according to the results of DXA in children and adolescents can be calculated as low with the Z-criterion <-2 SD in accordance with the age and gender of the child $[14,15]$.

All calculations were carried out on a computer using Microsoft Office Excel 2010 and STATISTIKA6. Differences between groups were considered statistically significant at $p<0.05$.

\section{Results And Discussion.}

The control group's mean age was $13.2 \pm 2.8$ years, the youngest was a boy whose debut of Graves' disease began at 2 years and 5 months, the oldest was 18 years old. Of these, there were 8 children (24.2\%), 25 adolescents (75.8\%), where there were 21 girls (63.6\%), 12 boys (36.4\%). The group with thyrotoxicosis was similar in terms of these indicators and did not have significant differences: the average age was $12.3 \pm 1.6$ (9-18 years old), there were 4 children ( $21.1 \%), 15$ adolescents $(78.9 \%)$, girls $11(57.9 \%), 8$ boys (42.1\%).

The average height of children and adolescents with GD was $151.9 \pm 2.7 \mathrm{~cm}$, weight $39.4 \pm 2.3 \mathrm{~kg}$, body mass index (BMI) $16.6 \pm 0.6$, body surface area (BSA) $1.3 \pm 0.05 \mathrm{~m} 2$. At the same time, $57.6 \%$ (19) of children in the group with thyrotoxicosis were found to be underweight, $9.1 \%$ (3) were found to be overweight and obese, these children had a history of a hypothalamic syndrome of puberty at the time of 
the development of Graves' disease. Anthropometric data of children and adolescents with Graves' disease by percentiles are presented in Table 1 .

Table 1.Anthropometric data of children and adolescents with GD by percentiles.

\begin{tabular}{|lllll|}
\hline Percentiles & Height, cm & Weight, kg & BMI, kg / m2 & BSA, m2 \\
\hline Percentile 3 & 123,8 & 20,0 & 12,0 & 0,8 \\
\hline Percentile 5 & 124,6 & 20,6 & 12,2 & 0,9 \\
\hline Percentile 10 & 133,2 & 22,4 & 13,1 & 1,0 \\
\hline Percentile 25 & 142,0 & 27,0 & 13,9 & 1,0 \\
\hline Median 50 & 157,0 & 40,0 & 16,3 & 1,3 \\
\hline Percentile 75 & 163,0 & 52,0 & 19,2 & 1,5 \\
\hline Percentile 90 & 168,8 & 55,6 & 20,5 & 1,6 \\
\hline Percentile 93.5 & 173,6 & 56,0 & 21,2 & 1,7 \\
\hline Percentile 95 & 174,4 & 56,8 & 21,3 & 1,7 \\
\hline Percentile 97 & 175,1 & 58,0 & 21,7 & 1,7 \\
\hline
\end{tabular}

Indicators of children's thyroid status with Graves' disease indicate thyrotoxicosis and a significant difference compared to the control group (Table 2).

Table 2.Thyroid status of the examined children and adolescents

\begin{tabular}{|llll|}
\hline Indicators & GD, M \pm SD & Control group, M $\pm S D$ & $p$ \\
\hline TSH $(0.28-4.3 \mathrm{mlU} / \mathrm{ml})$ & $0,007 \pm 0,001$ & $2,5 \pm 0,8$ & $\mathrm{p}<0,001$ \\
\hline fT3 $(2.5-4.3 \mathrm{ng} / \mathrm{dl})$ & $24,5 \pm 1,5$ & $3,8 \pm 0,8$ & $\mathrm{p}<0,001$ \\
\hline fT4 $(1.1-1.8 \mathrm{ng} / \mathrm{dl})$ & $6,4 \pm 0,2$ & $1,5 \pm 0,3$ & $\mathrm{p}<0,001$ \\
\hline TPOAb (up to $34 \mathrm{IU} / \mathrm{ml})$ & $387 \pm 30,6$ & $17,8 \pm 8,3$ & $\mathrm{p}<0,001$ \\
\hline TSHRAb (up to $1.75 \mathrm{IU} / \mathrm{l})$ & $24,3 \pm 1,2$ & $1,0 \pm 0,4$ & $\mathrm{p}<0,001$ \\
\hline (p<0.05, $\mathrm{p}<0.01$ - in relation to the control group) & \\
\hline
\end{tabular}

In $15.2 \%$ (5) adolescents with Graves' disease, the highest threshold for determining the level of antibodies to TSH receptors was revealed, indicating pronounced immune aggression of thyrotoxicosis. The median thyroid status in the group of children and adolescents with thyrotoxicosis is presented in Table 3.

Table 3.Thyroid status of children and adolescents with GD by percentiles 


\begin{tabular}{|c|c|c|c|c|c|}
\hline Percentiles & $\mathrm{TSH}, \mathrm{mlU} / \mathrm{ml}$ & $\mathrm{fT} 3, \mathrm{ng} / \mathrm{dl}$ & $\mathrm{fT} 4, \mathrm{ng} / \mathrm{dl}$ & TPOAb, IU/ml & TSHRAb, IU/I \\
\hline Percentile 3 & 0,001 & 6,9 & 3,9 & 85,5 & 9,7 \\
\hline Percentile 5 & 0,001 & 8,0 & 4,3 & 93,7 & 10,2 \\
\hline Percentile 10 & 0,001 & 11,7 & 4,7 & 117,8 & 10,5 \\
\hline Percentile 25 & 0,001 & 20,0 & 5,3 & 263,7 & 14,2 \\
\hline Median 50 & 0,005 & 25,9 & 6,5 & 441,5 & 25,0 \\
\hline Percentile 75 & 0,01 & 30,7 & 7,6 & 514,0 & 32,4 \\
\hline Percentile 90 & 0,012 & 32,4 & 7,8 & 584,0 & 40,0 \\
\hline Percentile 93.5 & 0,015 & 32,5 & 7,8 & 584,0 & 40,0 \\
\hline Percentile 95 & 0,017 & 33,2 & 7,8 & 593,1 & 40,0 \\
\hline Percentile 97 & 0,019 & 34,4 & 7,8 & 607,7 & 40,0 \\
\hline
\end{tabular}

In the study of bone metabolism indicators, it was revealed that the average value of the vitamin $D$ level in the control group was $20.4 \pm 6.2 \mathrm{ng} / \mathrm{ml}$. The median baseline calcidiol level in the analysed group was $21.1 \mathrm{ng} / \mathrm{ml}$. The worst provision with vitamin $D$ was demonstrated by children: the concentration of $25(\mathrm{OH}) \mathrm{D}$ in them was $18.5 \pm 5.4 \mathrm{ng} / \mathrm{ml}$, in adolescents, the average level of vitamin $\mathrm{D}$ was higher and amounted to $21.8 \pm 7.0 \mathrm{ng} / \mathrm{ml}$, but the difference was insignificant. The analysis demonstrates that only 2 $(8.7 \%)$ children of the control group had optimal values of $25(\mathrm{OH}) \mathrm{D}$ concentration (Fig. 1).

In the group with thyrotoxicosis, the average vitamin D level was $9.8 \pm 1.1 \mathrm{ng} / \mathrm{ml}$. The median baseline calcidiol level in the analysed group was $9.5 \mathrm{ng} / \mathrm{ml}$. In this group, on the contrary, adolescents showed the worst provision with vitamin $\mathrm{D}$ : the concentration of $25(\mathrm{OH}) \mathrm{D}$ in them was $11.4 \pm 1.3 \mathrm{ng} / \mathrm{ml}$, in children with GD, the average level of vitamin $D$ was higher and amounted to $15.5 \pm 5,4 \mathrm{ng} / \mathrm{ml}, p>0.05$ compared between children and adolescents. None of the patients had an optimal concentration of $25(\mathrm{OH}) \mathrm{D}$ (Fig. 1).

The results obtained indicate that even considering sufficient insolation in the Republic of Uzbekistan, $43.4 \%$ of children and adolescents without endocrine pathology revealed a vitamin D deficiency. At the same time, vitamin D deficiency was 2 times more frequent in the group with thyrotoxicosis (87.8\% (29)), and its failure was observed in $12.2 \%$ (4) of pediatric patients.

The analysis of the parameters of parathyroid hormone (PTH) in the children and adolescents under study showed no less exciting patterns that, undoubtedly, not only affect the current processes of phosphorus-calcium metabolism but, apparently, have a severe impact on the processes of bone mineralisation in children and adolescents. The average level of parathyroid hormone in the control group was $49.2 \pm 4.3 \mathrm{ng} / \mathrm{ml}$. In this group, the average PTH values in the blood serum in children were 1.5 times less than in adolescents and amounted to $38.6 \pm 2.2 \mathrm{ng} / \mathrm{ml}$ and $57.4 \pm 5.7 \mathrm{ng} / \mathrm{ml}$, respectively. Of these, 1 (4.3\%) was diagnosed with a decrease in the PTH level of less than $15 \mathrm{ng} / \mathrm{ml}, 6(26.1 \%)$ had an increased 
PTH level. In the group with thyrotoxicosis, the average parathyroid hormone level was significantly lower than in the control group and amounted to $45.1 \pm 4.9 \mathrm{ng} / \mathrm{ml}, \mathrm{p}<0.05$.

On the contrary, in this group, the mean values of PTH in the blood serum in children were 1.2 times higher than in adolescents and amounted to $51.8 \pm 2.3 \mathrm{ng} / \mathrm{ml}$ and $43.4 \pm 3.1 \mathrm{ng} / \mathrm{ml}$, respectively, but the difference was not reliable. In the group with thyrotoxicosis, hypoparathyroidism was 6.3 times more common than among healthy children (27.3\% (9)). Simultaneously, $8(24.2 \%)$ showed an increase in more than $65 \mathrm{ng} / \mathrm{ml}$ PTH levels.

Table 4.DXA indicators in the studied children and adolescents.

\begin{tabular}{|c|c|c|c|c|c|c|c|c|}
\hline \multirow[t]{2}{*}{ Group } & \multicolumn{2}{|c|}{$\begin{array}{l}\text { BMD femoral } \\
\text { neck, g/cm2 (M } \\
\pm \text { SDS) }\end{array}$} & \multicolumn{2}{|c|}{$\begin{array}{l}\text { Femur Z- } \\
\text { score }\end{array}$} & \multirow{2}{*}{$\begin{array}{l}\text { BMD of the } \\
\text { spine } L 1-L 4, \\
\text { g/cm2 }(M \pm \\
\text { SDS) }\end{array}$} & \multirow{2}{*}{$\begin{array}{l}\text { Z- } \\
\text { score } \\
\text { L1- } \\
\text { L4 }\end{array}$} & \multirow{2}{*}{$\begin{array}{l}\text { BMD } \\
\text { total, } \\
\text { g/cm2 } \\
\text { (M士 } \\
\text { SDS) }\end{array}$} & \multirow[t]{2}{*}{$\begin{array}{l}\text { Total } \\
\text { Z- } \\
\text { score }\end{array}$} \\
\hline & right & left & right & left & & & & \\
\hline Control, $n=23$ & $\begin{array}{l}0,804 \\
\pm 0,16\end{array}$ & $\begin{array}{l}0,801 \\
\pm 0,18\end{array}$ & 0,3 & 0,4 & $0,776 \pm 0,19$ & 0,5 & $\begin{array}{l}0,718 \pm \\
0,14\end{array}$ & $-0,3$ \\
\hline $\begin{array}{l}\text { Thyrotoxicosis, } \\
n=19\end{array}$ & $\begin{array}{l}0,863 \\
\pm 0,18\end{array}$ & $\begin{array}{l}0,878 \\
\pm 0,2\end{array}$ & $-0,8^{\star}$ & $-0,9 *$ & $0,798 \pm 0,28$ & $-0,6^{*}$ & $\begin{array}{l}0,770 \pm \\
0,15\end{array}$ & $-0,7^{\star}$ \\
\hline
\end{tabular}

The medians of the Z-scores of the FN on the right and left, the lumbar vertebrae L1-L5 and the body as a whole in the group of children and adolescents with thyrotoxicosis were significantly lower than the control values. They testified to osteoporosis in this group, where $p \leq 0.01$ in all indicators compared with the control group (Fig. 2).

Thus, the results obtained indicate the presence of vitamin D deficiency in $87.8 \%$ of children and adolescents with thyrotoxicosis, and $12.2 \%$ were found to be deficient in this hormone. It is possible that vitamin D deficiency, which has an immunosuppressive effect, is also a provoking factor in the development of thyrotoxicosis caused by Graves' disease $[18,19,20]$.

When determining the relationship between vitamin D concentration and the level of antibodies to TSHR, we established a significant association between the content of 25(OH)D and the value of TSHRAb in the group of patients with GD. The correlation analysis results indicate GD patients' meaningful feedback between the vitamin $D$ content and the level of TSHRAb $(r=-0.38 ; p<0.05)$. Our results suggest an association between vitamin $D$ deficiency and autoimmune-induced thyroid dysfunction. Low vitamin $D$ levels are possibly the primary factor involved in the pathogenesis of the disease.

In a study by Ahn HwaYoung et al. (2017) evaluated the correlation between serum 25(OH)D2 levels and thyroid-stimulating antibodies (TSAb) in 143 adult GD patients. Regression analysis of the risk ratio (RR) and the confidence interval $(\mathrm{Cl})$ revealed that high levels of bT4 (>1.4ng/dL; RR 3.252; 95\% Cl 1.022$10.347)$ correlated with low levels of $25(\mathrm{OH}) \mathrm{D} 2(\leq 14,23 \mathrm{ng} / \mathrm{ml})$, and, accordingly, with a higher 
likelihood of developing /recurrent GD (RR, 3.016; 95\% Cl, 1.163-7.819). Thus, the authors concluded that the level of 25(OH)D2 in serum may be an independent risk factor in predicting Graves' disease's development and recurrence [19].

There is no consensus about the change in the level of PTH in the blood during thyrotoxicosis. According to the literature data, thyrotoxicosis is accompanied by an increase in PTH concentration, normalising during successful therapy [21]. Although there are opposite works, indicating hypoparathyroidism in Graves' disease [22]. According to our results, in the group with thyrotoxicosis, hypoparathyroidism occurred 4.9 times more often than among healthy children $(24.2 \%)$.

Formation of peak bone mass is a crucial stage in age-related development of the skeleton and a critical physiological moment that determines bone strength throughout the entire subsequent life of a person [5, 23]. In adults, thyrotoxicosis causes severe osteoporosis and increases the risk of fractures, but when compensation is quickly achieved, a significant BMD decrease is not observed. Subclinical hyperthyroidism is also associated with low BMD and an increased risk of fractures [24]. However, there are practically no data on children. According to the DXA results obtained by us at the time of the study in children and adolescents with thyrotoxicosis, the Z-scores of the femoral neck on the right and left, lumbar vertebrae and the common body were significantly lower than the control, in $63.6 \%$ osteoporosis was diagnosed, in $24.2 \%$ - osteopenia. However, at the moment, we cannot determine whether osteoporosis is secondary as a complication of thyrotoxicosis, or it is of mixed aetiology, also associated with vitamin $D$ deficiency.

\section{Conclusions.}

1. The average value of the vitamin $D$ level in the control group was $20.4 \pm 6.2 \mathrm{ng} / \mathrm{ml}$, in the group with thyrotoxicosis $-9.8 \pm 1.1 \mathrm{ng} / \mathrm{ml}, \mathrm{p}<0.05$. At the same time, vitamin D deficiency was revealed in $43.4 \%$ of children and adolescents without endocrine pathology. In the group with thyrotoxicosis, vitamin $D$ deficiency was diagnosed in $87.8 \%$, and its deficiency - in $12.2 \%$ of pediatric patients.

2. The average level of parathyroid hormone in the control group was $49.2 \pm 4.3 \mathrm{ng} / \mathrm{ml}$. In contrast, in the group with thyrotoxicosis, the average parathyroid hormone level was significantly lower and amounted to $45.1 \pm 4.9 \mathrm{ng} / \mathrm{ml}, \mathrm{p}<0.05$. In the group with thyrotoxicosis, hypoparathyroidism was 6.3 times more frequent than among healthy children; an increase in PTH levels of more than $65 \mathrm{ng} / \mathrm{ml}$ was found in $24.2 \%$.

3. According to the results of X-ray densitometry in children and adolescents with thyrotoxicosis, the mean values and the median of the Z-score of the FN, lumbar vertebrae, and palpation were significantly lower than in the control group. Moreover, in the control group, $4.2 \%$ of adolescents were diagnosed with juvenile osteoporosis. Simultaneously, in the group with thyrotoxicosis, $63.6 \%$ had osteoporosis, $p \leq 0.01$, and $24.2 \%$ had osteopenia. 
4. Thyrotoxicosis in children and adolescents causes a decrease in BMD and increases osteoporosis development by almost 15 times.

\section{Declarations}

Ethics approval and consent to participate in the study were approved by the ethical committee of the RCSPMS at the scientific council \# 1 dated January 7, 2021.

\section{Consent for publication}

Consent was obtained from parents and guardians to conduct the research and publish data.

\section{Availability of data and materials}

The datasets used and/or analyzed during the current study are available from the corresponding author on reasonable request.

\section{Competing interests}

The authors declare that they have no competing interests.

\section{Funding}

The source of funding for the reported study is the RSSPMC at the expense of the applied grant No. PZ2017091941.

\section{Authors' contributions}

The development of the study, collection, analysis and interpretation of data, and the writing of the manuscript were carried out by the author, Muratova Sh.T.

\section{Acknowledgments}

The author is grateful to Professor Anvar Valievich Alimov for his support in carrying out this study.

\section{References}

1. Zvyagin AA, Bavykina IA, Pochivalov AV at al.. Mineral density condition of bone tissue in healthy children vs. patients on a gluten-free diet. Pediatrics. Journal named after G.N. Speransky. 2015;4:141-145. (In Russ.).

2. Shcheplyagina LA, Kruglova IV, Moiseeva TYu. Istoki osteoporoza vzroslykh lezhat v detskom vozraste. Lechenie i profilaktika. 2013;1:5-12. (In Russ.) IDR: 14336856.

3. Tyrtova DA, Erman MV, Tyrtova LV at al. Osteoporoz v detskom i podrostkovom vozraste: sostoyanie problemy. Soobshchenie 1. Vestnik Sankt-peterburgskogo universiteta. 2009;11(2):164-177. (In 
Russ.) .

4. Kljuchnikov SO, Kravchuk DA, Ogannisyan MG. Osteoporosis in children and its relevance for pediatric sports medicine. Vestn Perinatol i Pediatr. 2017;62:(3):112-20. DOI:10.21508/1027-40652017-62-3-112-120. (in Russ).

5. Maltsev SV, Mansurova GSh. Modern aspects of osteoporosis in children. Practical Medicine. 2015;7(92):15-21. (in Russ).

6. Numbenjapon N, Costin G, Pitukcheewanont P. Normalization of cortical bone density in children and adolescents with hyperthyroidism treated with antithyroid medication. Osteoporos Int. 2012;23:2277-82. doi:10.1007/s00198-011-1867-8.

7. Masalova NN, Zakharenko RV. Sostoyanie fosforno-kal'tsievogo obmena i kostnogo metabolizma v norme i pri narushenii funktsii shchitovidnoy zhelezy. Dal'nevostochnyy meditsinskiy zhurnal. 2009;2:122-5. (in Russ).

8. Bassett JH, Williams GR. Role of thyroid hormones in skeletal development and bone maintenance. EndocrRev. 2016;37(2):135-87. doi:10.1210/er.2015-1106.

9. Muratova Sh T, Alimov AV Mineral density of bone tissue, parathyroid hormone and vitamin D in children and adolescents with thyrotoxicosis // 22nd European Congress of Endocrinology e-ECE 2020. 5-9 September 2020, Endocrine Abstracts (2020) Vol 70, AEP193. DOI:

10.1530/endoabs.70.AEP193.

10. Verbovaya MV. .Mineral'naya plotnost' kostnoy tkani, pokazateli ee metabolizma i kal'tsiy-fosfornogo obmena u bol'nykh tireotoksikozom. Osteoporoz i osteopatii. 2002;1:13-6. (in Russ).

11. WHO Scientific Group on the Prevention and Management of Osteoporosis. Geneva, Switzerland;2000. ISBN 9241209216.

12. Melnichenko GA, Belaya Zh E, Rozhinskaya LYa at al. Russian federal clinical guidelines on the diagnostics, treatment, and prevention of osteoporosis. Problems of Endocrinology 2017;63(6):392426. (in Russ) doi: 10.14341/probl2017636392-426.

13. Rizzoli R, Boonen S, Brandi MI. Review vitamin D supplementation in elderly or postmenopausal women: a 2013 update of the 2008 recomendations from the European Society for Clinical and Economic Aspects of osteoporosis and Osteoarthritis (ESCEO). Curr Med Res Opin. 2013 Apr;29(4):305-13. doi:10.1185/03007995.2013.766162.

14. Gabel L, Macdonald HM, McKay HA. Reply to: Challen gesin the Acquisition and Analysis of Bone Microstructure During Growth. J Bone Miner Res. 2016 Dec;31(12):2242-3. doi:10.1002/jbmr.3010.

15. Skripnikova IA, Shcheplyagina LA, Novikov VE. i dr. Vozmozhnosti kostnoy rentgenovskoy densitometrii v klinicheskoy praktike. Metodicheskie rekomendatsii. Vtoroe izdanie, dopolnennoe. Moskva;2015. (in Russ).

16. Niyazova NF, Anvarova Sh. S.Nekotorye pokazateli mineral'noy plotnosti kostnoytkani i kal'tsiyfosfornogo obmena u bol'nykhtireotoksikozom v usloviyakh yodnogo defitsita. Paemi Sino (Vestnik Avitsenny). 2010;3:100-4. (in Russ). 
17. Muratova Sh T. Osteoporosis as complication of tierotoxicosis. Pediatric aspects. Pediatrics Journal. 2018;2:61-5. (in Russ).

18. Muratova Sh. Deficiency of vitamin D as a potential factor of the development of Graves' disease in children and adolescents. 47th Annual Meeting of the British Society for Paediatric Endocrinology and Diabetes 2019. 27-29 November 2019, Cardiff, United Kingdom. Endocrine Abstracts. (2019) Vol 66. P.84. https://www.endocrine-abstracts.org/ea/0066/abstractbook. DOI: 10.1530/endoabs.66.P84.

19. Ahn HY, Chung YJ, Cho BY. Serum 25-hydroxyvitamin D might be an independent prognostic factor for Graves' disease recurrence. Medicine. 2017 Aug;96(31):e7700. doi:10.1097/MD.0000000000007700.

20. Nettore IC, Albano L, Ungaro P, at al. Sunshine vitamin and thyroid. Rev Endocr Metab Disord. 2017 Sep;18(3):347-354. doi: 10.1007/s11154-017-9406-3.

21. Meek CL, Kaplan F, Pereira RS, et al. Hypocalcemia following treatment for hyperthyroidism.Clin Chem. 2011 Jun;57(6):811-4. doi: 10.1373/clinchem.2010.150375.

22. Miyashita K, YasudaT., KanetoH., et al. A Case of hypocalcemia with severe vitamin D deficiency following treatment for Graves' disease with methimazole. Case Rep Endocrinol. 2013; 2013: 512671, doi: 10.1155/2013/512671.

23. Mansurova GSh, Maltsev SV. Osteoporosis in children - the role of calcium and vitamin D in prevention and therapy. Practical Medicine. 2017;5(106):55-9. (in Russ).

24. Williams GR, Bassett JHD. Thyroid diseases and bone health. J Endocrinol Invest. 2018 Jan;41(1):99-109. doi: 10.1007/s40618-017-0753-4.

\section{Figures}

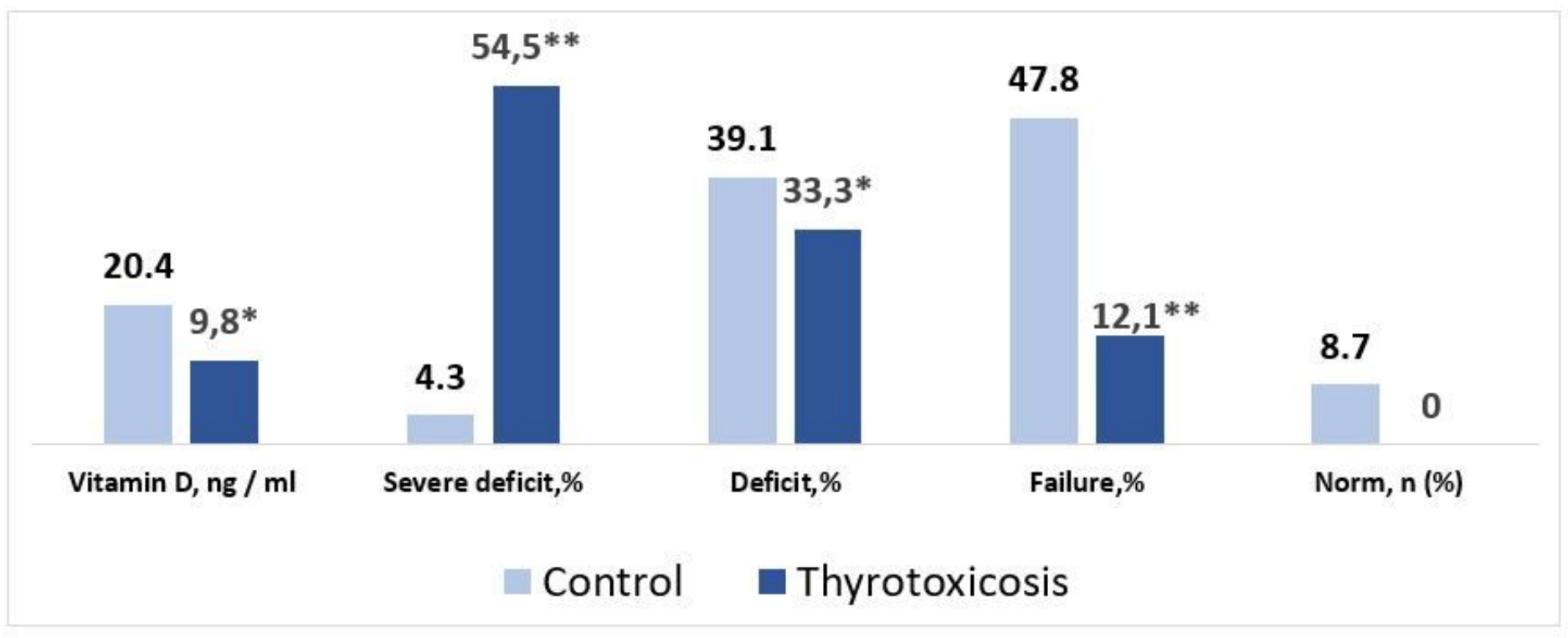


Vitamin D serum levels in children and adolescents with thyrotoxicosis and control. ${ }^{*}-p<0.05,{ }^{*}-p<0.01$ in comparison with the control group.

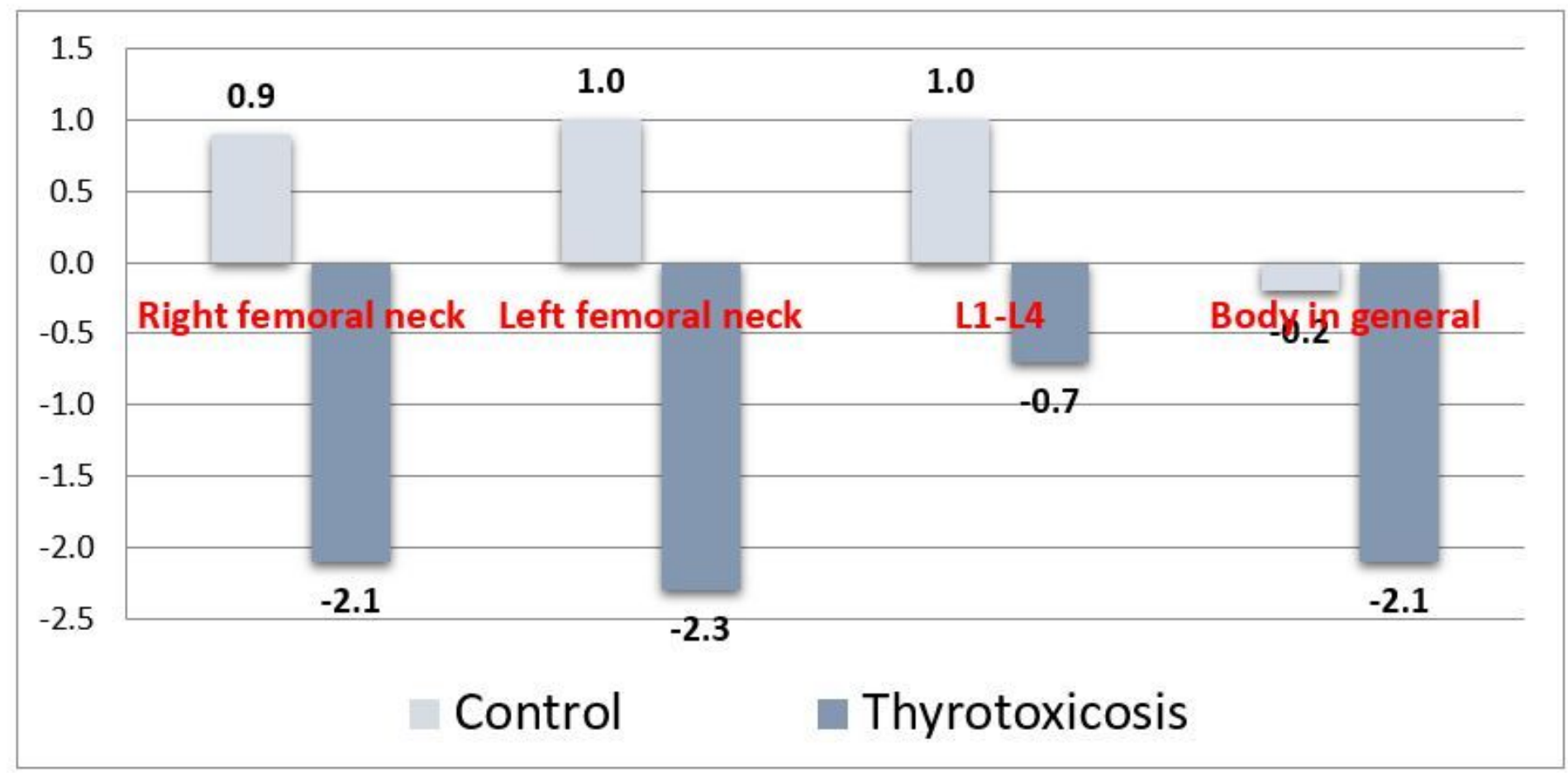

\section{Figure 2}

Medians of Z-score according to the results of DXA in the studied groups, $*-p \leq 0.01$ 